\title{
EFEKTIVITAS MODEL PEMBELAJARAN NUMBERED-HEADS- TOGETHER UNTUK MENINGKATKAN HASIL BELAJAR SISWA PADA MATERI AKHLAK KELAS X (Studi Quasi Eksperimen di Kelas X MIPA SMAN 7 BANDUNG)
}

\author{
Eneng Dewi Zaakiyah*, \\ Abas Asyafah, Udin Supriadi \\ Program Studi Ilmu Pendidikan Agama Islam \\ Fakultas Pendidikan Ilmu Pengetahuan Sosial, Universitas Pendidikan Indonesia \\ *E-mail : zaakiyahenengdewi@yahoo.co.id
}

\begin{abstract}
ABSTRAK
Penelitian ini dilatarbelakangi oleh kenyataan bahwa siswa acuh terhadap pembelajaran PAI, karena tidak ada dalam ujian nasional. Kenyataan inilah yang menyebabkan siswa meremehkan pelajaran PAIdan mereka pun sering menganggap bahwa dalam pembelajaran PAI monoton dan membosankan, sehingga beberapa siswa kurang menguasai materi pembelajaran PAI. Kurangnya penggunaan model pembelajaran modern dalam penyampaian materi-materi PAI, menjadi salah satu permasalahan yang diindikasikan membuat siswa kurang menangkap materi pembelajaran. Beranjak dari latar belakang tersebut, serta dilihat dari kelebihan dan karakteristik, diindikasikan bahwa model numbered heads together dapat menyelesaikan problem yang terjadi dan harapannya dapat meningkatkan hasil belajar siswa. Adapun tujuan dari penelitian ini adalah untuk mengetahui efektivitas penggunaan model pembelajarannumbered heads together dalam meningkatkan hasil belajar siswa pada materi akhlak kelas X MIA di SMA Negeri 7 Bandung. Pendekatan yang digunakan dalam penelitian ini adalah pendekatan kuantitatif dengan metode eksperimen jenis nonequivalent control group design. Pengambilan sampel menggunakan nonprobability sampling. Teknik pengumpulan data diperoleh dari tes tulis berbentuk pilihan ganda. Teknik analisis datanya menggunakan analisis deskriptif dan statistik dengan bantuan aplikasi SPSS versi 21. Hasil penelitian menunjukkan bahwa pengolahan data dengan menggunakan uji independent sample test data post-test kelas eksperimen dan kontrol, menunjukkan nilai sig. (2-tailed) sebesar 0,000 yang artinya lebih kecil dari 0,05. Sesuai dasar pengambilan keputusan dalam uji independent sample $t$ test, jika nilai sig.(2-tailed) $<0,05$ maka $\mathrm{H}_{\mathrm{a}}$ diterima dan $\mathrm{H}_{0}$ ditolak atau dengan kata lain terdapat perbedaan yang signifikan antara kelas eksperimen dan kontrol dalam peningkatan hasil belajar siswa pada materi akhlak kelas X. Dengan demikian, model pembelajaran numbered heads together efektif dalam meningkatkan hasil belajar siswa pada materi akhlak kelas X di SMA Negeri 7 Bandung.
\end{abstract}

Kata Kunci: Akhlak, Hasil Belajar, Model Numbered-Heads-Together. 


\section{PENDAHULUAN}

Dunia pendidikan telah berkembang seiring dengan pesatnya perkembangan ilmu pengetahuan, teknologi telekomunikasi dan komputer. Kepesatan tersebut telah mengantarkan masyarakat menuju era globalisasi. Globalisasi ini ditandai dengan meningkatnya keragaman kehidupan dalam masyarakat. Setiap individu di zaman ini dituntut untuk mengembangkan kreativitas dan mampu beradaptasi dengan situasi global yang makin bervariasi dan cepat berubah. Untuk itu, setiap individu harus memiliki keterampilan yang kompleks.

Manusia adalah makhluk Allah yang diciptakan dalam bentuk sebaik-baiknya. Ia dibekali akal agar senantiasa berfikir dan mengembangkan potensinya. Sebagaimana menurut Jalaluddin (dalam Mubarok, t.t, hlm. 109) bahwa "potensipotensi yang diberikan kepada manusia pada dasarnya merupakan petunjuk (hidayah) dari Allah agar manusia dapat melakukan sikap hidup yang serasi dengan hakikat penciptaannya". Mengenai potensi yang diberikan Allah kepada manusia, Umar (2010, hlm. 19) mengemukakan bahwa "Allah menciptakan manusia bukan secara main-main, melainkan dengan suatu tujuan dan fungsi sebagai khalifah Allah. Untuk melaksanakan fungsi ini, Allah membekali manusia dengan seperangkat potensi. Dalam hal ini, salah satu cara untuk mengantarkan ke arah pengembangan potensi adalah dengan pendidikan".

Mengenai pendidikan, Nugraha dkk. (2014, hlm. 55) mengemukakan bahwa "pendidikan merupakan kebutuhan pokok bagi seluruh manusia, karena setiap manusia ketika baru dilahirkan ke dunia tidak mengetahui apapun". Kemudian menurut Ramayulis (2011, hlm. 38) dalam UU RI Nomor 20 tahun 2003 bab II pasal 3 dijelaskan bahwa "tujuan pendidikan nasional yaitu untuk mengembangkan potensi peserta didik agar menjadi manusia yang beriman dan bertakwa kepada Tuhan Yang Maha Esa, berakhlak mulia, sehat, berilmu, cakap, kreatif, mandiri dan menjadi warga Negara yang demokratis serta bertanggung jawab".

Dengan membentuk manusia yang beriman dan bertakwa kepada Tuhan Yang Maha Esa, berakhlak mulia, sehat, berilmu, cakap, kreatif, mandiri dan menjadi warga Negara yang demokratis serta bertanggung jawab tentu kemajuan bangsa ini dapat dicapai. Oleh karenanya, demi mewujudkan tujuan pendidikan nasional di atas, maka upaya sekolah dapat dilaksanakan melalui Pendidikan Agama Islam. Bagaimana pun juga Pendidikan Agama Islam merupakan pendidikan yang secara khusus mengembangkan nilai-nilai dan ajaran Islam serta mengembangkan potensi peserta didik dalam hal keagamaan. Terutama dalam meningkatkan iman dan takwa peserta didik serta menjadikan mereka menjadi manusia yang berakhlak mulia.

Berbicara mengenai akhlak dijelaskan oleh Zahruddin \& Sinaga (2004, hlm. 14) bahwa "akhlak adalah mutiara hidup yang membedakan manusia dengan hewani. Manusia tanpa akhlak adalah manusia yang telah membinatang, sangat berbahaya. Ia akan lebih jahat dan lebih buas dari binatang buas".

Oleh karenanya, jika akhlak sudah hilang dari diri manusia, maka kehidupan ini akan berantakan. Orang-orang tidak akan lagi peduli terhadap masalah baik, buruk, halal dan haram.

Untuk mengaktualisasikan hal-hal di atas dapat terimplementasi dalam berbagai bentuk model pembelajaran. Model-model pembelajaran tersebut tentunya dapat dilaksanakan dalam pembelajaran PAI di sekolah.

Salah satu sekolah yang dapat melaksanakan model pembelajaran tersebut adalah SMA Negeri 7 Bandung. Sebagaimana sekolah ini adalah lembaga pendidikan yang sangat menjunjung keberhasilan pembelajaran, sehingga para siswa yang dihasilkan mampu ikut serta dan berperan dalam persaingan global. 
Namun berdasarkan kajian peneliti, pembelajaran PAI di sekolah tidak dipandang menarik oleh siswa. Kurang menariknya proses pembelajaran PAI salah satunya disebabkan oleh beberapa guru yang masih menggunakan metode dan model konvesional, lagi-lagi membaca ayat, menerjemahkan, menghafal ayat dan mendengarkan ceramah dalam menerima materi, sehingga siswa mengeluh jenuh, bosan, kurang semangat dalam mengikuti pelajaran. Hal ini pun memberikan efek buruk pada hasil belajar siswa.

Hal tersebut terbukti dari data awal yang diperoleh dari salah satu guru PAI kelas X SMAN 7 Bandung, dari 3 kelas dengan jumlah siswa 84 orang sebanyak 50 siswa atau 59,52\% yang nilai ulangan harian bab 6-nya di bawah KKM. Data tersebut menunjukkan bahwa pemahaman belajar siswa masih kurang optimal, sehingga hasil yang didapatkan tidak sesuai dengan yang diharapkan.

Selain itu, Budi dkk. (2015, hlm. 193) mengemukakan bahwa kurang menariknya pembelajaran PAI disebabkan anggapan siswa bahwa PAI tidak penting karena tidak ada dalam ujian nasional. Untuk mengatasi agar pembelajaran PAI di sekolah tidak membosankan dan tidak monoton, PAI harus dikemas lebih menarik melalui suatu model yang dapat menarik perhatian siswa.

Salah satu model yang dapat digunakan guna menjawab permasalahanpermasalahan dalam pembelajaran dan untuk mengaktifkan proses pembelajaran di kelas, serta untuk meningkatkan hasil belajar siswa yaitu dengan menerapkannya model pembelajaran Numbered heads together. Muslimin (2000, hlm. 65) mengemukakan bahwa numbered heads together adalah salah satu tipe dari pembelajaran kooperatif dengan sintaks: pengarahan, kelompok heterogen dan tiap siswa memiliki nomor tertentu, berikan materi bahan ajar kemudian bekerja dalam kelompok, presentasi kelompok dengan nomor siswa yang sama sesuai dengan tugas masing-masing sehingga terjadi diskusi di kelas, kuis individual pun dibuat dan buat skor perkembangan tiap siswa, umumkan hasil kuis dan beri reward.

Model ini dapat diterapkan tentunya dengan memiliki beberapa kelebihan. Adapun kelebihan dari metode Numbered Heads Together sebagaimana menurut Ibrahim (dalam Yusnita, 2015, hlm. 22) bahwa (1) rasa harga diri menjadi lebih tinggi; (2) memperbaiki kehadiran; (3) perilaku mengganggu menjadi lebih kecil; (4) konflik antara pribadi berkurang; (5) pemahaman lebih mendalam; (6) tidak ada istilah numpang nama; (7) meningkatkan kebaikan budi, kepekaan dan toleransi; (8) hasil belajar lebih tinggi.

\section{METODE}

Penelitan ini dilaksanakan di SMA Negeri 7 Bandung yang terletak di Jl. Lengkong Kecil No. 53, Kelurahan Paledang, Kecamatan Lengkong-Kota Bandung pada semester genap tahun ajaran 2015/2016 dari bulan April sampai Mei 2016. Pada penelitian ini yang menjadi subjek penelian adalah seluruh siswa kelas X SMA Negeri 7 Bandung. Sedangkan yang dijadikan sebagai sampel adalah siswa kelas X MIA 1 dan X MIA 3 yang masing-masing kelasnya berjumlah 35 siswa.

Pendekatan yang digunakan dalam penelitian ini adalah pendekatan kuantitatif. Sementara, metode yang digunakan adalah metode penelitian eksperimen. Sugiyono (2014, hlm. 107) mengemukakan bahwa "dalam penelitian eksperimen terdapat perlakuan (treatment). Penelitian eksperimen adalah metode penelitian yang digunakan untuk mencari pengaruh perlakuan tertentu terhadap yang lain dalam kondisi yang terkendalikan".

Adapun desain penelitian yang digunakan dalam penelitian ini adalah desain quasi experimental dengan jenis desain eksperimen Nonequivalent control group design. Dimana pada desain ini kelompok eksperimen maupun kontrol dipilih dengan teknik nonprobability 
sampling atau tidak dipilih secara random. Instrumen yang digunakan dalam penelitian ini berupa tes objektif dengan bentuk soal pilihan ganda. Dalam menjawab pertanyaan responden diberikan pilihan a, b, c, d, dan e dalam setiap pertanyaan. Soal dibuat sendiri oleh peneliti berdasarkan kurikulum 2013 tingkat SMA. Kemudian soal yang diberikan saat pre-test dan post-test berjumlah 58 soal. Untuk mengetahui perbandingan hasil tes, maka soal yang digunakan untuk pre-test dan post-test adalah soal yang sama dengan proses pengujian sebagai berikut.

\section{Statistik Deskriptif}

Data yang dianalisis secara deskriptif adalah data hasil belajar siswa. Adapun analisis deskriptif ini meliputi pengolahan skor menjadi nilai. Untuk menginterpretasikan nilai tersebut, digunakan interpretasi sesuai Permendikbud No. 104 Tahun 2014 tentang Penilaian Hasil Belajar.

\section{Gain Ternormalisasi}

Analisis data gain ternormalisasi digunakan untuk mengetahuiterdapat atau tidaknya peningkatan nilai pre-test dan post-test oleh kelas eksperimen dan kontrol. Untuk menghitung besarnya gain ternormalisasi dicari dengan rumus:

$$
G T=\frac{\text { Npre }- \text { Npost }}{\text { Nmaks }- \text { Npre }}
$$

$$
\begin{array}{ll}
\text { Keterangan: } & \\
\text { GT } & =\text { Gain ternormalisasi } \\
\text { Npre } & =\text { Nilai pre-test } \\
\text { Npost } & =\text { Nilai post-test } \\
\text { Nmaks } & =\text { Nilai maksimum }
\end{array}
$$

Adapun interpretasi dari gain ternormalisasi adalah sebagai berikut.

Tabel Interpretasi Gain Ternormalisasi

\begin{tabular}{|c|c|}
\hline GAIN & INTERPRETASI \\
\hline $\mathrm{g} \geq 0,7$ & Tinggi \\
\hline $\begin{array}{c}0,7>\mathrm{g} \geq \\
0,3\end{array}$ & Sedang \\
\hline $\mathrm{g}<0,3$ & Rendah \\
\hline
\end{tabular}

Sumber: Hake (dalam Gordah \& Fadillah, 2014, hlm. 347).

\section{Uji Hipotesis}

a. Uji Normalitas

Uji normalitas yaitu untuk mengetahui normal atau tidaknya distribusi sebaran data. Dalam uji normalitas, peneliti menggunakan teknik chi square.

Adapun ketentuannya adalah jika nilai chi kuadrat ${ }_{\text {hitung }}<$ chi kuadrat $t_{\text {tabel }}$ maka $\mathrm{H}_{\mathrm{o}}$ diterima dan $\mathrm{H}_{\mathrm{a}}$ ditolak, berarti data berdistribusi normal, sedangkan jika nilai chi kuadrat $t_{\text {hitung }}>$ chi kuadrat $t_{\text {tabel }}$ maka $\mathrm{H}_{\mathrm{o}}$ ditolak dan $\mathrm{H}_{\mathrm{a}}$ diterima, berarti data berdistribusi tidak normal.

Selain itu, dapat pula dengan melihat signifikansi asymp. Signifikansi asymp ini dapat dilihat dari output SPSS pengolahan data dengan Chi Square. Adapun ketentuannya adalah jika nilai signifikansi asymp > 0,05 maka data berdistribusi normal, sedangkan jika nilai signifikansi asymp $<0,05$ maka data berdistribusi tidak normal.

b. Uji Homogenitas

Uji homogenitas yaitu untuk mengetahui varians kedua sample homogen atau tidak. Dalam pengujian homogenitas varians, peneliti menggunakan uji F. Kriteria dalam pengujian homogenitas dengan uji $\mathrm{F}$ yaitu, jika $\mathrm{F}_{\text {hitung }}<\mathrm{F}_{\text {tabel }}$ maka $\mathrm{H}_{\mathrm{o}}$ diterima dan $\mathrm{H}_{\mathrm{a}}$ ditolak, berarti varian kedua kelompok data tersebut adalah homogen. Jika sebaliknya $\mathrm{F}_{\text {hitung }}>\mathrm{F}_{\text {tabel }}$ maka $\mathrm{H}_{\mathrm{o}}$ ditolak dan $\mathrm{H}_{\mathrm{a}}$ diterima, dapat dinyatakan bahwa varian kedua kelompok data tersebut adalah tidak homogen (Sugiyono, 2013, hlm. 199).

\section{c. Pengujian Hipotesis}

Dalam pengujian hipotesis, jika sampel penelitian kurang dari 100 responden, maka pengujian hipotesis menggunakan uji t-test. Sedangkan jika sampel penelitian lebih dari 100 responden, maka pengujian hipotesis menggunakan uji z. Dalam penelitian ini sampel penelitian berjumlah 70 orang, maka pengujian hipotesis yang dugunakan adalah uji t-test. 
Dalam pengujian uji t-test, terdapat dua jenis uji t-test yaitu, uji t-test parametrik dan non parametrik. Uji t-test parametrik merupakan uji yang dilakukan jika data memenuhi syarat berdistribusi normal dan homogen. Sedangkan uji t-test non parametrik merupakan uji yang dilakukan jika data tidak berdistribusi normal dan tidak homogen.

Uji t-test parametrik dikelompokkan dalam dua pengujian, yaitu:

1) Uji independent sample t test, yaitu membandingkan rata-rata nilai pretest atau post test pada kelompok yang berbeda.

2) Uji paired sample $t$ test, yaitu membandingkan rata-rata nilai pretest dan post test pada kelompok yang sama.

Adapun ketentuan uji t parametrik adalah Jika nilai sig. (2-tailed) $>0,05$ maka tidak terdapat perbedaan yang signifikan antara kelas eksperimen dan kelas kontrol. Sedangkan jika nilai sig. (2tailed) $<0,05$ maka terdapat perbedaan yang signifikan antara kelas eksperimen dan kelas kontrol. Dalam pengolahan analisis data, seluruhnya peneliti menggunakan bantuan aplikasi SPSS versi 21.

\section{HASIL DAN PEMBAHASAN}

Kondisi awal hasil belajar siswa kelas eksperimen dengan data nilai pretest ditemukan bahwa rata-rata nilai pretest kelas eksperimen sebesar 46,77 dan interpretasi nilainya kurang. Sedangkan untuk kelas kontrol, ditemukan rata-rata nilai pre-test sebesar 49,09 dengan interpretasi nilai kurang. Kemudian dilakukan pengujian perbedaan rata-rata nilai pre-test kelas eksperimen dan kontrol dengan uji independent sample $T$ Test dengan bantuan aplikasi SPSS versi 21 . Diperoleh bahwa nilai sig. (2-tailed) sebesar 0,276 yang artinya lebih besar dari 0,05. Dengan demikian, dapat diketahui bahwa tidak terdapat perbedaan yang signifikan antara nilai rata-rata pre-test kelas eksperimen dan kelas kontrol.

Setelah dilaksanakan pre-test di kelas eksperimen dan kontrol, selanjutnya diberikan treatment. Adapun untuk penerapan model pembelajaran numbered heads together berlangsung pada kegiatan inti dengan maksud untuk mengumpulkan informasi dengan cara berkelompok dan untuk setiap anggota kelompok memiliki nomor masing-masing 1 sampai 5 . Sebagaimana Nuryanti (2009, hlm. 372) mengungkapkan bahwa numbered heads together artinya berpikir bersama secara penomoran. Model ini melibatkan lebih banyak peserta didik dan fungsinya untuk mengecek pemahaman peserta didik terhadap materi pelajaran. Di lain pihak, diungkap oleh Gustaviana \& Yunansah (2013) bahwa numbered heads together merupakan model pembelajaran yang menggunakan sistem belajar dan bekerja dalam kelompok kecil berjumlah 4-6 orang secara kolaboratif sehingga dapat merangsang siswa lebih bergairah dalam pembelajaran. Model ini juga berbasiskan student centre yang dapat memfasilitasi semua siswa untuk aktif dalam pembelajaran dan saling membagikan ideidenya satu sama lain.

Setelah selesai berdiskusi, kemudian peneliti memanggil salah satu nomor dari kelompok tertentu untuk mempresentasikan hasil diskusi kelompoknya. Setelah presentasi, kemudian peneliti memanggil salah satu nomor dari kelompok yang lain untuk memberikan tanggapan. Langkah ini senada dengan yang diungkapkan oleh Kagan (dalam Riyanto, 2009, hlm. 273) bahwa langkah-langkah dalam Model Pembelajaran numbered heads together adalah:

a. Siswa dibagi ke dalam kelompok, setiap siswa dalam setiap kelompok mendapat nomor;

b. Guru memberikan tugas dan masingmasing kelompok mengerjakannya;

c. Kelompok mendiskusikan jawaban yang benar dan memastikan tiap 
anggota kelompok dapat mengerjakannya/ mengetahui jawabannya;

d. Guru memanggil salah satu nomor siswa dengan nomor yang dipanggil melaporkan hasil kerja sama mereka;

e. Tanggapan dari teman yang lain, kemudian guru menunjuk nomor yang lain;

f. Pemberian kesimpulan.

Secara keseluruhan, treatment dilakukan sebanyak empat kali pertemuan, ditambah dengan 2 pertemuan untuk pretest dan post-test. Adapun materi yang dibahas yaitu materi tentang akhlak, khususnya bab tentang nikmatnya mencari ilmu dan indahnya berbagi pengetahuan; dan tentang menjaga martabat manusia dengan menjauhi pergaulan bebas dan zina. Untuk penjelasan mengenai langkahlangkah pembelajaran pada setiap pertemuan, dipaparkan pada lampiran Rancangan Pelaksanaan Pembelajaran (RPP). Untuk langkah-langkah pembelajaran antara kelas eksperimen dan kontrol tidak jauh berbeda, yang membedakan hanya pada kegiatan inti saja.

Pada saat pembelajaran dengan model numbered heads together siswa terlihat cukup antusias dan aktif dalam kelompoknya, mereka berusaha untuk menjadi yang terbaik mewakili kelompoknya. Hal ini pun senada dengan yang diungkap oleh Ibrahim (dalam Yusnita, 2015, hlm. 22) bahwa "kelebihan model ini yaitu rasa harga diri menjadi lebih tinggi; memperbaiki kehadiran; perilaku mengganggu menjadi lebih kecil; konflik antar pribadi berkurang; pemahaman lebih mendalam; tidak ada istilah numpang nama; meningkatkan kebaikan budi, kepekaan dan toleransi; hasil belajar lebih tinggi".

Selanjutnya dilakukan post-test di kelas eksperimen dan kontrol. Dari data nilai post-test, diketahui kondisi akhir hasil belajar siswa kelas eksperimen sebesar 79,51 dengan interpretasi baik. Sedangkan untuk kondisi akhir hasil belajar siswa kelas kontrol ditunjukkan dengan rata-rata nilai post-test sebesar 70,8 dengan interpretasi cukup.

Untuk melihat adanya peningkatan hasil belajar siswa kelas eksperimen, maka selanjutnya dianalisis dengan gain ternormalisasi. Gain ternormalisasi merupakan gain yang digunakan untuk mengetahui ada atau tidaknya peningkatan hasil belajar setelah diberikan treatment.

Dari pengolahan data gain ternormalisasi, menunjukkan bahwa siswa kelas eksperimen mengalami peningkatan sebesar 0,62 dengan interpretasi sedang. Untuk mengetahui apakah peningkatan yang terjadi meningkat secara signifikan atau tidak, maka data pre-test dan post test kelas eksperimen diuji dengan uji paired sample $t$ test, dengan syarat data berdistribusi normal dan homogen.

Setelah data pre-test dan post test diketahui normal dan homogen, maka data dihitung dengan uji paired sample t test yang perhitungannya dibantu dengan aplikasi SPSS versi 21. Diperoleh bahwa nilai sig. (2-tailed) sebesar 0,000 yang artinya lebih kecil dari 0,05. Dengan demikian, dapat disimpulkan bahwa terdapat perbedaan yang signifikan antara nilai rata-rata pre-test dan post-test kelas eksperimen. Hal ini menunjukkan bahwa siswa kelas eksperimen mengalami peningkatan hasil belajar yang signifikan setelah diberikan treatment dengan model pembelajaran Numbered Heads Together.

Sedangkan pengolahan data dengan gain ternormalisasi kelas kontrol, menunjukkan bahwa peningkatan pemahaman belajar sebanyak 0,37 dengan interpretasi sedang. Untuk mengetahui apakah terdapat peningkatan yang signifikan atau tidak, maka data pre-test dan post test diuji dengan uji paired sample $t$ test dengan syarat data berdistribusi normal dan homogen.

Setelah data pre-test dan post test diketahui normal dan homogen, maka data dihitung dengan uji paired sample t test dengan bantuan aplikasi SPSS versi 21 . 
Diperoleh bahwa nilai sig. (2-tailed) sebesar 0,000 yang artinya lebih kecil dari 0,05 . Dengan demikian, dapat disimpulkan bahwa terdapat perbedaan yang signifikan antara nilai rata-rata pre-test dan post-test kelas kontrol. Hal ini menunjukkan bahwa siswa kelas kontrol mengalami peningkatan hasil belajar yang signifikan setelah melaksanakan proses pembelajaran.

Selanjutnya dilakukan pengujian hipotesis. Untuk melihat adanya perbedaan yang signifikan antara kelas eksperimen dan kontrol, maka data yang didapat dari kedua kelas tersebut diolah dengan uji independent sample $t$ test. Adapun data yang akan digunakan untuk pengujian hipotesis dengan uji independent sample $t$ test yaitu menggunakan data nilai post-test kelas eksperimen dan kontrol.

Setelah data post-test kelas eksperimen dan kontrol diketahui berdistribusi normal dan homogen, maka data diolah dengan uji independent sample $t$ test dengan bantuan aplikasi SPSS versi 21 yang hasilnya sebagai berikut.

Diketahui nilai sig. (2-tailed) sebesar 0,000 yang artinya lebih kecil dari 0,05, maka $\mathrm{H}_{\mathrm{a}}$ diterima dan $\mathrm{H}_{0}$ ditolak. Dengan kata lain terdapat perbedaan yang signifikan antara rata-rata hasil belajar post-test siswa yang melakukan pembelajaran dengan menggunakan model pembelajaran numbered heads together dengan siswa yang tidak menggunakan model pembelajaran numbered heads together dalam meningkatkan hasil belajar siswa pada materi akhlak kelas X.

\section{KESIMPULAN}

Berdasarkan uji hipotesis, dapat disimpulkan bahwa terdapat perbedaan yang signifikan antara kelas eksperimen yang menggunakan model pembelajaran numbered heads together dengan kelas kontrol yang tidak menggunakan model pembelajaran numbered heads together dalam proses pembelajaran PAI khususnya pada materi akhlak kelas $\mathrm{X}$. Dengan demikian, model pembelajaran numbered heads together efektif dalam meningkatkan hasil belajar siswa pada materi akhlak kelas $\mathrm{X}$ di SMA Negeri 7 Bandung.

Adapun rekomendasi bagi peneliti selanjutnya yaitu model pembelajaran numbered heads together bisa diterapkan pada ruang lingkup PAI di luar materi akhlak yang tentunya dengan memperhatikan kelebihan dan kekurangan model ini. Sehingga rekomendasinya yaitu adanya perbandingan pembelajaran PAI dengan model pembelajaran kooperatif yang lain dan diharapkan dari perbandingan dua model tersebut mampu meningkatkan hasil belajar siswa dalam proses pembelajaran PAI.

\section{REFERENSI}

Budi, Rahmat, M., \& Kosasih, A. (2015). Efektivitas CD Interaktif dalam Pembelajaran Pendidikan Agama Islam untuk Meningkatkan Hasil Belajar Siswa SMP. Jurnal Pendidikan Agama Islam-Ta'lim, 13 (2), 191-200.

Gordah, E. K., \& Fadillah, S. (2014). Pengaruh Penggunaan Bahan Ajar Kalkulus Diferensial Berbasis Pendekatan Open Ended terhadap Kemampuan Representasi Matematis Mahasiswa. Jurnal Pendidikan dan Kebudayaan, 3 (20), hlm. 340-352.

Gustaviana, T. D., \& Yunansah, H. (2013). Pengaruh Pembelajaran Kooperatif Tipe NHT Terhadap Hasil Belajar Siswa pada Konsep Energi dan Perubahannya. Antologi, 1 (2).

Kementerian Pendidikan dan Kebudayaan Republik Indonesia. (2014, Oktober 8). Penilaian Hasil Belajar oleh Pendidik pada Pendidikan Dasar dan Pendidikan Menengah. Peraturan Menteri Pendidikan dan Kebudayaan Nomor 104 tahun 2014. Mubarok, R. (t.thn.). Strategi Pendidikan Islam dalam Meningkatkan Kualitas 
Sumber Daya Manusia. Jurnal elHikmah Fakultas Tarbiyah UIN Maliki Malang, 102-128.

Muslimin. (2000). Pembelajaran Kooperatif. Surabaya: Unesa University Press.

Nugraha, M. S., Supriadi, U., \& Anwar, S. (2014). Pembelajaran PAI Berbasis Media Digital. Jurnal Penelitian Agama Islam-Ta'lim, 12 (1), 55-66.

Nuryanti, L. (2009). Model dan Media Pembelajaran Bisnis dengan Penerapan Kooperatif Team Game Tournament. Dalam B. Alma, \& R. Hurriyanti (Penyunt.), Manajemen Corporate \& Strategi Pemasaran Jasa Pendidikan (hal. 363-396). Bandung: Alfabeta.

Ramayulis. (2011). Ilmu Pendidikan Islam. Jakarta: Kalam Mulia.
Riyanto, Y. (2009). Paradigma Baru Pembelajaran: Sebagai Referensi bagi Guru/Pendidik dalam Implementasi Pembelajaran yang Efektif dan Berkualitas. Jakarta: Kencana Prenada Media Group.

Sugiyono. (2014). Metode Penelitian Pendidikan Pendekatan Kuantitatif, Kualitatif dan $R \& D$. Bandung: Alfabeta.

(2013). Statistika untuk Penelitian. Bandung: Alfabeta.

Umar. (2010). Ilmu Pendidikan Islam. Jakarta: Amzah.

Yusnita, E. (2015). Menerapan Metode Kooperatif Numbered Heads Together dalam Meningkatkan Keaktifan dan Pemahaman Materi Pastry. Dinamika, 5 (4), 20-27. 